\title{
Developing web-based health guidance for coaches and parents in child athletics (track and field)
}

Jenny Jacobsson, Joakim Ekberg, Toomas Timpka, Lena Rasberg, Marina Sjoberg, Dejan Mirkovic and Sverker Nilsson

The self-archived postprint version of this journal article is available at Linköping University Institutional Repository (DiVA):

http://urn.kb.se/resolve?urn=urn:nbn:se:liu:diva-165517

N.B.: When citing this work, cite the original publication.

Jacobsson, J., Ekberg, J., Timpka, T., Rasberg, L., Sjoberg, M., Mirkovic, D., Nilsson, S., (2020), Developing web-based health guidance for coaches and parents in child athletics (track and field), Scandinavian Journal of Medicine and Science in Sports, 30(7), 1248-1255.

https://doi.org/10.1111/sms.13661

Original publication available at:

https://doi.org/10.1111/sms.13661

Copyright: John Wiley and Sons

http://www.wiley.com/ 


\section{Developing web-based health guidance for coaches and parents in child athletics (track and field)}

Jenny Jacobsson, ${ }^{1,2,3}$ Joakim Ekberg, ${ }^{1,3}$ Toomas Timpka, ${ }^{1,3}$ Lena Haggren Råsberg, ${ }^{2}$ Marina Sjöberg, ${ }^{2}$ Dejan Mirkovic, ${ }^{2}$ Sverker Nilsson ${ }^{2}$

${ }^{1}$ Athletics Research Center, Linköping University, Linköping, Sweden

${ }^{2}$ Swedish Athletics Association, Stockholm, Sweden

${ }^{3}$ Department of Medical and Health Sciences, Linköping University, Linköping, Sweden

Word count (excluding title page, abstract, references, figures and tables): 3317

Keywords: Track and field; Prevention; Sports injury; Health Guide; Internet; Youth

Correspondence to: Jenny Jacobsson PT, PhD, Department of Medical and Health Sciences, Faculty of Health Sciences, Linköping University, SE-581 83 Linköping, Sweden; jenny.jacobsson@liu.se 


\section{Abstract}

The aim of this study was to develop athletics health guidance (AHG) aimed at supporting coaches and parents involved in organised child athletics by providing practical advice and tools for the management of the most common health problems experienced in athletics by the 12 to 15 -year olds. The study used participatory action research (PAR) and an established health service guideline development procedure modified to fit AHG development in child athletics. A sequential process consisting of four steps with associated sub-goals was employed. The collected data were structured according to the AHG development steps and analysed using qualitative methods. The most common health concern identified was injuries related to growth and overuse. No randomized controlled studies investigating injury prevention programmes or any existing concepts/guidelines in child athletics were found that could be used in the development of the AHG. A requirements document was instead defined in a nominal group process and used for the AHG development. The areas included in the final AHG were: training youth athletes, growth and puberty, recovery, injury prevention, injuries and illnesses, mental illness, safe sport and anti-doping. The evidence regarding health issues in child athletics is limited, indicating that actions to support good health in the sport are currently based essentially on best practice. The long-term aim of the AHG and associated website is to systematically create and introduce conditions that can bridge the "know-do gap" and provide coaches and parents with easy-to-access and up-to-date knowledge in the field of child athlete health in athletics. 


\section{INTRODUCTION}

Health promotion is the empowerment of individuals and groups to improve their control over their own health, including specific activities aimed at populations at increased risk. ${ }^{1}$ It has been suggested that whether a sport organization has a proactive or reactive attitude towards health questions has decisive influence on young sportspeople long-term progress in settings with high demands on athletic performance. ${ }^{2}$ Current research also suggests that a reflective and holistic approach is beneficial for successfully developing talent and to maintain athlete health in child sport. $^{3-5}$ The reason put forward is that due to growth and maturation, children are particularly susceptible to issues associated with their musculoskeletal system, hormonal regulation, and psychological makeup when exercising. ${ }^{6} \mathrm{~A}$ dynamic and strongly interactive approach is therefore required when planning and providing support to talented young sportspeople. In the child athletes's environment, coaches and parents are the people having the best possibilities to influence a child athlete's development. $^{5}$

Health guidance denotes systematically developed recommendations on specific topics aimed at promoting health in particular settings or groups based on the best available evidence. ${ }^{7}$ With ubiquitous Internet access through smartphones, it has become common in households with children to first seek information online when a health issue is encountered. ${ }^{8}$ However, it may be difficult for parents and other guardians to review online health information and assess its validity. 9,10 Health guidance can be compared with clinical guidelines, which are recommendations for clinicians regarding the handling of specific conditions based on available research evidence and best practice experience. ${ }^{7}$ Recent research in adult sports has shown 
that validated sports medicine information obtained from expert professionals is highly valued and considered as a reliable source of information. ${ }^{11}$

Knowledge about health guidance for coaches and parents who support talented child athletes is scarce. The long-term purpose of an ongoing participatory research programme, involving researchers and representatives from various levels of Swedish Athletics, is to develop a safe and sustainable training framework for child athletics athletes. ${ }^{5}$ The aim of this study was to develop health guidance for coaches and parents involved in child athletics by providing practical advice and tools in the management of the most common health problems experienced in the sport by 12 to 15-year olds. The recommendations in the athletics health guidance (AHG) are to be systematically based on the best-identified current level of evidence and/or best practice.

\section{METHOD}

This study used participatory action research (PAR) - a research method that involves reflective processes directly linked to action. ${ }^{12}$ The study involved child athletics coaches and parents, sports administrators and officials, researchers, and clinical professionals (doctors, physical therapists) associated with the Swedish Athletics federation. An established health service guideline development procedure, ${ }^{13}$ modified to fit AHG development in child athletics was used. While implementing the procedure, the researchers simultaneously collected and stored data. A sequential process consisting of the following four steps and associated subgoals was used for the AHG development; 
1) Establishing the process; sub goals 1.1 Define and recruit participants. 1.2 Define the problem/area that needs to be addressed.

2) Identifying health problems in child athletics; sub goals 2.1 Review of peerreviewed and grey literature to identify epidemiological or experimental studies. 2.2 Survey of a reference population.

3) Identifying recommendations for the management of identified health problems; sub goals 3.1 Search the Internet. 3.2 Review of peer-reviewed and grey literature to identify any additional existing concepts

and

4) Guideline preparation and distribution; sub goals 4.1 prepare best evidence and/or best practice. 4.2 Develop a website and publish recommendations.

The process and methods used in the different steps are described in more detail together with the results. The study was approved by the board of Swedish Athletics and is reported according to the RIGHT checklist for guideline development. ${ }^{14}$

\subsection{Study participants and setting}

The primary end-user population for the AHG was coaches and parents in child athletics (age group 12-15 years). The primary investigator $(\mathrm{JJ})$ contacted Swedish Athletics and asked for interest to participate in the study (see also sub goals 1.1 and 2.2). According to the principles of PAR, coaches, parents of child athletes, and practitioners from Swedish Athletics participated actively with researchers and software engineers as co-designers of the AHG throughout the project. Most of the equipment used in the project, as well as the researchers' and software engineers' salaries, was covered by grants from national development agencies; costs for the 
participation of practitioners, auxiliary equipment, and office space were covered by Swedish Athletics.

\subsection{Data collection}

Data concerning interventions and their outcomes were collected continuously by the researchers from field notes, memos from meetings, transcripts from audio and video recordings, project reports, and project diaries and stored by the primary investigator $(\mathrm{JJ})$ in a study database.

\subsection{Data analysis}

Analyses of the data were performed in two steps. First, the data were structured according to the AHG development plan i.e., the four-step sequential process. Thereafter, data concerning the design decisions within each project phase were analysed using thematic analysis. ${ }^{15}$ This method consists of 6 phases that provide structure for qualitative data to be organized, coded and themes identified. Finally, the outcomes of the decisions were assessed and documented. During the year four "face to face" meetings were conducted, in each meeting the practitioners participated actively in interpretation of outcomes and in drawing conclusions from the research to reach agreement on the proposed action. To support the presentation of the process interventions for a general audience, thus making it possible to evaluate actions planned and taken in the design process, the results are presented with regard to the project plan.

\section{RESULTS}

The AHG was discussed continuously in the PAR group during each step in order to reach efficient consensus on the final recommendations. 
Step 1. Establishing the process

\section{Sub goal 1.1}

Define and recruit participants to the PAR group.

\section{Actions and outcomes}

The primary investigator $(\mathrm{JJ})$ contacted senior practitioners $(n=8)$ at Swedish Athletics involved with the national team about participation. Two practitioners declined participation due to workload. One researcher (JE) with expertise in usability research and public health informatics was recruited from Linköping University. The final working group (also referred to as experts) consisted of six participants: two physicians (SN, LHR), one physiotherapist (JJ), one nutritionist (MS), one public health scientist (JE) and one athletics coach (DM).

Sub goal 1.2

Define the problem/area that needs to be addressed and which media to use for distribution of AHG.

\section{Actions and outcomes}

Considering the primary target population for the AHGs, it was decided to include universal prevention and early secondary prevention in health areas covered by the website. ${ }^{16}$ An Internet platform (a website specifically developed for the project) was proposed for translation of the AHG to the athletics community. The reason for choosing a website solution instead of a smartphone application was to easily enable updates and addition of materials such as videos and document files for printing. A smartphone application was also expected to require frequent software updates to be made by the user as smartphone technology constantly evolves. 
Step 2. Identifying health problems in youth athletics

Sub goal 2.1

Review of peer-reviewed and grey literature to identify epidemiological or experimental studies (or other reports like randomised clinical trials) that have examined the occurrence of possible health problems in child athletics in the 12-15 years age group.

\section{Actions and outcomes}

A literature search (MeSH terms: athletics; track and field; adolescent; youth; child; injuries; prevention; health) identified seven epidemiological studies in athletics including athletes aged 5-18 years (table 1). ${ }^{17-23}$ These studies showed that the sport is burdened with a large proportion of injuries related to overuse. Lower limbs were the most common reported body location and common injury types varied among the studies. No randomized controlled studies investigating injury prevention programmes in child athletics were found.

\section{Sub goal 2.2}

Survey of a reference population.

Actions and outcomes

A cross-sectional web-survey containing free-text questions was performed among a reference population $(n=27)$ of coaches and parents who participated in a previous study (5) and that had reported interest in participating in future studies. Information was collected on their experiences from "health problems among child athletics athletes aged 12-15 years". The question asked was: "What are the most common health problems (injuries, illnesses, or other) you have encountered in your role as coach/parent for child athletes aged 12-15 years? You may want to list several 
items". Both coaches and parents reported that, from their respective perspectives, they had had to manage musculoskeletal health problems like shin splints, and sprained ankles and those related to growth, e.g. heel pain, Osgood Schlatter disease, (table 2). They also reported having had to deal with child athletes enduring psychosocial stress, often in conjunction with poor sleep. Regarding causes of ill health among the young athletes, the coaches and parents were particularly worried that the athletes' involvement with social media could lead to disturbed sleeping habits and insufficient recovery from training and competitions.

Step 3. Identifying recommendations for the management of the health problems identified

\section{Sub goal 3.1}

Search the Internet to identify any existing concepts, guidelines, or tools that could be used in the development of the current guidelines in athletics.

\section{Actions and outcomes}

The websites of the key stakeholders in athletics, the International Athletics Associations Federation (IAAF), European Athletics Associations (EAA), and the major English-speaking national athletics federations were scanned to identify any existing concepts, guidelines, or tools that could be used in the development of the current health guidance. No web pages containing health information addressing coaches and parents of these child athletics athletes could be identified. It was also recognized that information may have been missed due to that some websites where closed for access through requirements of organisational membership and password. 
Sub goal 3.2

Review of peer-reviewed and grey literature to identify any additional existing concepts and/or scope of knowledge on the health problems reported in Step 2 (MeSH terms: youth sport; adolescent; children; injuries; prevention; health; development).

\section{Actions and outcomes}

Three reports on youth athlete development describing recommendations for work in sporting bodies published by the International Olympic Committee (IOC) and one report from the National Strength and Conditioning Association (NSCA), USA, were identified. ${ }^{24-27}$ These statements emphasized the importance of a holistic approach and urged sports organizations to adopt and implement prevention policies. The following areas were stressed: general conditioning programmes, growth and puberty, injury prevention, mental illness, nutritional guidelines, eating disorders, sexual harassment policies, anti-doping.

\section{Step 4. Guideline preparation and distribution}

\section{Sub goal 4.1}

Use the nominal group method, ${ }^{28}$ that is a group process involving problem identification, solution generation, and decision making, to prepare best evidence and/or best practice recommendations for each of the outcomes identified in Steps 2 and 3 , including a quality assessment and a summary of the findings.

\section{Actions and outcomes}

The task communicated to the working group was to formulate requirements on topics to be highlighted on the website using their personal expertise as well as information gathered in Steps 2 and 3. The experts first provided their individual 
comments, which were collected by the primary investigator $(\mathrm{JJ})$. Formulation of suggested areas was performed independently, a requirements document was compiled and circulated to the entire expert group, and finally a consensus document was established. In the third and final step, the requirements/consensus document was approved by the expert group as the preliminary HG website design specification.

Sub goal 4.2

Develop a website and publish recommendations.

Actions and outcomes

The requirements document was used as the basis for the development of a website www.friskfriidrott.se (Healthy Athletics). The following areas, identified in Sub-goal 4.1, were included on the website: training child athletes, planning for training, growth and puberty, recovery, injury prevention, injuries and illnesses, mental illness, safe sport (sexual harassment, bullying, etc.) and anti-doping. Each member of the group was assigned an area in which they had expertise to collect information and formulate text with background material and guidelines for actions (table 3). Thus, the AHG was essentially formulated on level 5 evidence. Material was then submitted to the primary investigator $(\mathrm{JJ})$ who compiled the material and submitted it as published text on the website (figures 1-3).

\section{Sub goal 4.3}

Judge the overall quality of the evidence and the strength of recommendations for all the outcomes included. 
Actions and outcomes

The website was reviewed in two rounds: first, the expert group performed a cognitive walkthrough, ${ }^{28}$ then a group of external experts $(n=6)$ with a background in sports physical therapy, sports medicine and sports science (KB, JK, CS, ÖD, TT, KÖ) reviewed the website. Feedback and comments were mainly about expressions in the text. There were no questions regarding the content and recommendations given. To enable future implementation of the website the usefulness, usability and user satisfaction will be evaluated in a forthcoming study (ClinicalTrials.gov NCT03459313) amongst end-users and the primary target population.

\section{DISCUSSION}

\subsection{Principal findings}

Knowledge has been requested on how sports organisations can implement health guidance for child athletes provided by bodies such as the IOC in practice settings. ${ }^{29}$ This study used PAR methods in a national athletics federation to develop AHG specifically adjusted to meet the information needs of youth coaches and parents. It was found that there was limited information on the health situation in child athletics and that almost no materials were available for health promotion or the early management of disease and injury that can be mediated by coaches and parents/caregivers. As a consequence, the AHG was mainly to be formulated/based on best practice while the research progresses. ${ }^{30}$

\subsection{AHG for sustainable sports}

Although disease and injury prevention and health promotion measures overlap, there are notable differences between the two. While disease and injury prevention 
comes within the health care sector, health promotion activities are mainly conducted in the community and involve first-order and social determinants of health. ${ }^{2}$ Child athletics training in Sweden, as in many other countries, is usually performed in clubs and is commonly organized on a voluntary and non-profit basis. ${ }^{31}$ Barriers towards reaching those involved in community sport have been shown, and the gap between available knowledge and its application in practice is well known and the challenges translating research evidence for use by members of the sporting community have been highlighted. ${ }^{32}$ Studies in team sports have observed that coaches experience that coaching courses do not promote awareness around various injury prevention strategies. Recently, various initiatives to develop online resources have been made to try to find ways to facilitate this process. ${ }^{33,34}$

The development of the AHG used a participatory design engaging stakeholders and end users in the process of solving a design problem, thus providing ideas and solutions based on user needs and preferences that might not be evident to the researchers. ${ }^{35}$ The AHG is further intended to support a more sustainable development of policies and programmes to make it possible to more effectively influence health issues in child sports locally in clubs as well as at a national level.

\subsection{AHG content}

Health-related information is mostly available as medical reports and clinical guidelines, i.e. written for and directed to medical professionals and for the management of injured or ill athletes. However, health promotion, universal and primary prevention activities refer to entire populations of athletes. ${ }^{18} \mathrm{~A}$ number of prevention programmes, mainly for team sports, have demonstrated considerable effects from interventions on the occurrence of specific injury types among child 
athletes. ${ }^{36,37}$ In the PAR process used in this study, it was, nevertheless, agreed that the resulting AHG had to contain knowledge and hands-on tools in areas besides prevention of specific injuries, i.e. information about what happens in the body during puberty and maturation, identifying talent and training the child athlete, and guidance for early management of pain in vulnerable growth areas such as heels and knees. Although empirical studies exploring injury patterns (and other health concerns), as well as possible causal links, are basically lacking in child athletics, both the existing literature on child sports epidemiology and experience-based knowledge indicate that injuries associated both with the individual's growth as well as overuse are a major concern. In order to support positive child athlete development, a holistic approach has therefore been emphasized, so that other challenges, apart from injury prevention, can be recognized. ${ }^{25}$ This first version of the AHG thus comprised directed information for children regarding recovery, safe sports and anti-doping strategies.

\subsection{AHG quality assessment}

The use of, e.g. the GRADE system, ${ }^{38}$ is recommended to judge the quality and strength of evidence on clinical guidelines. Assessing the quality of general health information given in the AHG was found to be a complex task because there is little evidence available for the recommendations given. For example, it has recently been shown that clinical guidelines for musculoskeletal pain conditions in the general population are of inferior quality. ${ }^{39}$ Nonetheless, in a society with virtually infinite access to information, it is of utmost importance that a sports organization take responsibility for the information conveyed to its members. A recent report has highlighted the importance of website design with a clear layout and that the ownership must be obvious and convey trust or credibility. ${ }^{40}$ The AHG website was 
developed to fulfil these requirements. The co-designers of the website included researchers and practitioners, all with extensive experience in the field. In addition, all training and medical information on the website is in line with the latest scientific evidence, or best practice, and follows the recommendations provided from the Swedish Athletics Federation, the Swedish Sports Confederation and the Swedish National Board of Health and Welfare.

\subsection{Generalizability of sports medical knowledge to child sports}

In the PAR process, we observed that in sports e.g. athletics for which there is no scientific evidence generated from child sports, recommendations still can be found (e.g. websites, apps) on the use of, for example neuromuscular programmes aimed at reducing the risk of injury. However, many of these programs are developed at a general level and it is not always clear if the interventions/exercises recommended are suitable for both children and adult elite athletes in the sport. Should a painful knee problem in a 15-year-old training athletics be managed in a similar manner to the same problem a 28-year-old discus thrower? Is the origin of pain and the

mechanism leading to these "overuse" problems the same? Although the cause can be assumed to be similar in growing individuals, injury patterns have been shown to differ among child sports; for example, soccer has a high proportion of anterior cruciate ligament injuries, gymnastics involves wrist injuries and handball has shoulder injuries, indicating sport-specific relationships. ${ }^{41,42}$ This reinforces that health programmes introduced in a sport need to be contextualized both to the specific age and the social environment of the athletes. ${ }^{43}$ 


\subsection{Limitations of the study}

There are restrictions in the use of the PAR methodology; the need for recurring meetings among the participants might be both time and resource demanding. However, we found that the process was facilitated by many natural meeting points (e.g. national team activities) during the year during the first part of the work.

\subsection{Conclusions}

This study showed that there are shortcomings in the science regarding health issues in child athletics, indicating that actions to support good health in the sport are currently essentially based on best practices. Thus, in order to support development towards a healthy sport for both children and elderly elite athletes, more resources and cooperation between research and practice are needed. The long-term aim of the website www.friskfriidrott.se is to systematically create and introduce conditions that can bridge the "know-do gap" and provide coaches and parents with easy-toaccess and up-to-date knowledge in the field of health in child sports. ${ }^{44}$

\section{PERSPECTIVE}

The purpose of AHG is to provide coaches and parents with easy-to-access and upto-date knowledge in the field of health in child athletics. Furthermore, the athletic health guidance (AHG) is intended to support/inform the development of policies and programs in Swedish Athletics to make it possible to more effectively influence health issues in child sports locally in clubs as well as at a national level.

\section{ACKNOWLEDGEMENT}

We thank Jonas Andersson, Daniel Bergin, Kajsa Berglund, Örjan Dahlström, Tommy Eriksson, Sanja Halénius, Per-Olof Hansson, Jan Kowalski, Charlotte 
Schönbeck, Carin Tyrén and Klas Östberg for providing valuable input during the development of the website

\section{FUNDING}

The study received research grants and support for post-doctoral studies $(\mathrm{JJ})$ from the Swedish Centre for Sports Research (CIF) (FO2017-0010) and Swedish Athletics.

\section{CONFLICT OF INTEREST}

None.

\section{AUTHORS'CONTRIBUTION}

JJ conceived and designed the research project and coordinated the study development. JJ, JE, LHR, MS, DM and SN were involved in data collection. JJ, JE, TT, LHR, MS, DM and SN were involved in the analysis of the data. All authors made substantial contributions to data interpretation. JJ made a substantial contribution to drafting and writing the article. All authors were involved in revising the manuscript and final approval of the version to be published.

References

1. World Health Organization. WHO Handbook for Guideline Development. Geneva: WHO; 2012.

2. Geidne S, Quennerstedt M, Eriksson C. The youth sports club as a healthpromoting setting: an integrative review of research. Scand J Public Health 2013;41:269-83. 
3. Henriksen K, Stambulova N, Roessler KK. Successful talent development in track and field: considering the role of environment. Scand J Med Sci Sports 2010;20 (Suppl 2):122-32.

4. Suppiah HT, Low CY, Chia M. Detecting and developing youth potential: different strokes for different folks are warranted. $\mathrm{Br} J$ Sports Med 2015;49:878-82.

5. Jacobsson J, Bergin D, Timpka T, Nyce JM, Dahlström Ö. Injuries in youth track and field are perceived to have multiple-level causes that call for ecological (holistic-developmental) interventions: a national sporting community perceptions and experiences. Scand J Med Sci Sports 2018;28:348-55.

6. Malina RM, Rogol AD, Cumming SP, Coelho e Silva MJ, Figueiredo AJ. Biological maturation of youth athletes: assessment and implications. $\mathrm{Br} \mathrm{J}$ Sports Med 2015;49:852-859.

7. Kelly M, Morgan A, Ellis S, et al. Evidence based public health: a review of the experience of the National Institute of Health and Clinical Excellence (NICE) of developing public health guidance in England. Soc Sci Med 2010;71:1056-62.

8. Park E, Kim H, Steinhoff A. Health-related internet use by informal caregivers of children and adolescents: an integrative literature review. J Med Internet Res 2016;18:57.

9. Demiris G. Consumer health informatics: past, present, and future of a rapidly evolving domain. Yearb Med Inform 2016;Suppl 1:S42-7.

10. Bekker S, Finch CF Too much information? A document analysis of sport safety resources from key organisations BMJ Open 2016;6:e010877. doi: 10.1136/bmjopen-2015-010877

11. Gerbing K, Thiel A. Handling of medical knowledge in sport: athletes' medical opinions, information seeking behaviours and knowledge sources. Eur J Sport Sci 2016;16:141-8.

12. Baum F, MacDougall C, Smith D. Participatory action research. J Epidemiol Community Health 2006;60:854-7. 
13. Oxman AD. Grading quality of evidence and strength of recommendations. BMJ 2004;328:1490-4.

14. Chen Y, Yang K, Marušić A, et al.; for the RIGHT (Reporting Items for Practice Guidelines in Healthcare) Working Group. A reporting tool for practice guidelines in health care: the RIGHT Statement. Ann Intern Med 2017;166:128-32.

15. Braun V, Clarke V. Using thematic analysis in psychology. Qual Res Psychol 2006;3:77-101.

16. Jacobsson J, Timpka T. Classification of prevention in sports medicine and epidemiology. Sports Med 2015;45:1483-7

17. Orava S, Saarela J. Exertion injuries to young athletes: a follow-up research of orthopaedic problems of young track and field athletes. Am J Sports Med 1978;6:68-74.

18. Zaricznyj B, Shattuck LJ, Mast TA, Robertson RV, D'Elia G. Sports-related injuries in school-aged children. Am J Sports Med 1980;8:318-24.

19. Watson MD, DiMartino PP. Incidence of injuries in high school track and field athletes and its relation to performance ability. Am J Sports Med $1987 ; 15: 251-4$

20. Coulon L, Lackey G, Mok M, Nile D. A profile of little athletes' injuries and the prevention methods used. J Sci Med Sport 2001;4:48-58.

21. Rebella G, Edwards JO, Greene JJ, Husen MT, Brousseau DC. A prospective study of injury patterns in high school pole vaulters. Am J Sports Med 2008;36:913-20.

22. Huxley DJ, O'Connor D, Healey PA. An examination of the training profiles and injuries in elite youth track and field athletes. Eur J Sport Sci 2014;14:185-92.

23. Pierpoint LA, Williams CM, Fields SK, Comstock RD. Epidemiology of injuries in United States high school track and field: 2008-2009 through 2013-2014. Am J Sports Med 2016;44:1463-8. 
24. Mountjoy M, Armstrong N, Bizzini L, Blimkie C, Evans J, Gerrard D, Hangen J, Knoll K, Micheli L, Sangenis P, Van Mechelen W. IOC consensus statement: "training the elite child athlete". Br J Sports Med 2008;42;163-4.

25. Bergeron MF, Mountjoy M, Armstrong N, Chia M, Côté J, Emery CA, Faigenbaum A, Hall G Jr, Kriemler S, Léglise M, Malina RM, Pensgaard AM, Sanchez A, Soligard T, Sundgot-Borgen J, van Mechelen W, Weissensteiner JR, Engebretsen L. International Olympic Committee consensus statement on youth athletic development. $\mathrm{Br} \mathrm{J}$ Sports Med 2015;49:843-51.

26. Mountjoy M, Rhind DJ, Tiivas A, Leglise M. Safeguarding the child athlete in sport: a review, a framework and recommendations for the IOC youth athlete development model. Br J Sports Med 2015;49:883-6.

27. Lloyd RS, Cronin JB, Faigenbaum AD, Haff GG, Howard R, Kraemer WJ, Micheli LJ, Myer GD, Oliver JL. National Strength and Conditioning Association Position Statement on Long-Term Athletic Development. J Strength Cond Res. 2016 Jun;30(6):1491-509.

28. Jacobsson J, Timpka T, Ekberg J, Kowalski J, Nilsson S, Renström P. Design of a protocol for large-scale epidemiological studies in individual sports: the Swedish Athletics study. Br J Sports Med 2010;44:1106-11.

29. Mountjoy M, Bergeron M. Youth athletic development: aiming high while keeping it healthy, balanced and fun! Br J Sports Med 2015;49:841-2.

30. Minas $\mathrm{H}$, Jorm AF. Where there is no evidence: use of expert consensus methods to fill the evidence gap in low-income countries and cultural minorities. Int J Ment Health Syst 2010;4:33.

31. Dahlström Ö, Jacobsson J, Timpka T. Overcoming the organizationpractice barrier in sports injury prevention: a non-hierarchical organizational model. Scand J Med Sci Sports 2015;25:e414-22.

32. Finch CF. No longer lost in translation: the art and science of sports injury prevention implementation research. Br J Sports Med 2011;45:1253-7.

33. Glang AE, Koester MC, Chesnutt JC, Gioia GA, McAvoy K, Marshall $S$, Gau JM. The effectiveness of a web-based resource in improving 
postconcussion management in high schools. J Adolesc Health 2015;56:91-7.

34. Fulcher ML, Carlson I, Mitchell C, Bizzini M, Dvorak J. Development and implementation of the ACC SportSmart Warm-up programme: a nationwide sports injury prevention initiative in New Zealand. Br J Sports Med. 2018;52(20):1334-1338.

35. Lindblom H, Carlfjord S, Hagglund M. Adoption and use of an injury prevention exercise program in female football: a qualitative study among coaches. Scand J Med Sci Sports 2018;28:1295-303.

36. Waldén M, Atroshi I, Magnusson $\mathrm{H}$, Wagner $\mathrm{P}$, Hägglund M. Prevention of acute knee injuries in adolescent female football players: cluster randomised controlled trial. BMJ 2012;344:e3042.

37. Rössler R, Junge A, Bizzini M, Verhagen E, Chomiak J, Aus der Fünten $\mathrm{K}$, Meyer T, Dvorak J, Lichtenstein E, Beaudouin F, Faude O. A multinational cluster randomised controlled trial to assess the efficacy of '11+ Kids': a warm-up programme to prevent injuries in children's football. Sports Med 2018;48:1493-504.

38. Guyatt GH, Oxman AD, Vist GE, Kunz R, Falck-Ytter Y, Alonso-Coello $P$, Schünemann HJ. GRADE: an emerging consensus on rating quality of evidence and strength of recommendations. BMJ 2008;336:924-6.

39. Lin I, Wiles LK, Waller R, Goucke R, Nagree Y, Gibberd M, Straker L, Maher CG, O'Sullivan PPB. Poor overall quality of clinical practice guidelines for musculoskeletal pain: a systematic review. Br J Sports Med 2018;52:337-43.

40. Sbaffi L, Rowley J. Trust and credibility in web-based health information: a review and agenda for future research. J Med Internet Res 2017;19:e218.

41. Kox LS, Kuijer PP, Kerkhoffs, GM, Maas $\mathrm{M}^{1}$, Frings-Dresen MH. Prevalence, incidence and risk factors for overuse injuries of the wrist in young athletes: a systematic review. Br J Sports Med 2015;49:1189-96.

42. Moller M, Nielsen RO, Attermann J, Wedderkopp N, Lind M, Sørensen $\mathrm{H}$, Myklebust $\mathrm{G}$. Handball load and shoulder injury rate: a 31-week cohort study of 679 elite youth handball players. Br J Sports Med 2017;51:231-7. 
43. Rodríguez-Serrano LI, Timpka T, Ekberg J, Dahlström Ö, Jacobsson J. Young athletes' health knowledge system: qualitative analysis of health learning processes in adolescent sportspersons. Scand J Med Sci Sports 2018;28:1272-80.

44. Holt NL, Pankow K, Camiré M, Côté J, Fraser-Thomas J, MacDonald DJ, Strachan L,Tamminen KA. A qualitative study of research priorities among representatives of Canadian Provincial Sport Organization. Psychol Sport Exerc 2018;36:8-16.

Legends to tables and figure:

Table 1. Observational studies reporting injury incidence or prevalence in child athletics, arena events

Table 2. Results from the cross-sectional survey reference group of coaches and parents $(n=20)$ (all did not provide an answer to every question)

Table 3. Areas covered on the website www.friskfriidrott.se (Healthy Athletics): summary of information, recommendations and hands-on tools provided

Figure 1. Screenshot showing the home page on the website

Figure 2. Screenshot with menu of content on the website

Figure 3. Screenshot with examples of content available 
Table 1 Observational studies reporting injury incidence or prevalence in child athletics, arena events

\begin{tabular}{|c|c|c|c|c|c|c|c|c|c|}
\hline $\begin{array}{l}\text { Referen } \\
\text { ce }\end{array}$ & $\begin{array}{l}\text { Desi } \\
\text { gn }\end{array}$ & $\begin{array}{l}\text { Country } \\
\text {, setting }\end{array}$ & $\begin{array}{l}\text { No of } \\
\text { athletes } \\
\text { boys/gir } \\
\text { Is* }\end{array}$ & $\begin{array}{l}\text { Age } \\
\text { (year } \\
\text { s) }\end{array}$ & $\begin{array}{l}\text { Study } \\
\text { period }\end{array}$ & $\begin{array}{l}\text { Injury } \\
\text { incidence/prevale } \\
\text { nce }^{* *}\end{array}$ & $\begin{array}{l}\text { Injury } \\
\text { types }\end{array}$ & $\begin{array}{l}\text { Body } \\
\text { location* } \\
* *\end{array}$ & $\begin{array}{l}\text { Diagnosi } \\
\mathrm{S}^{\star \star \star}\end{array}$ \\
\hline \multicolumn{10}{|c|}{ Club/region } \\
\hline $\begin{array}{l}\text { Orava } \\
\text { et al. } \\
1978\end{array}$ & $\mathrm{P}$ & $\begin{array}{l}\text { Finland, } \\
\text { region, } \\
\text { events } \\
\text { na }\end{array}$ & $\begin{array}{l}48 \\
26 / 22\end{array}$ & $\begin{array}{l}10- \\
15\end{array}$ & $\begin{array}{l}2-3 \\
\text { years }\end{array}$ & $\begin{array}{l}\text { Incidence } \\
148 / 100 \text { athletes }\end{array}$ & $\begin{array}{l}\text { Overu } \\
\text { se } \\
63 \%\end{array}$ & $\begin{array}{l}\text { Knee } \\
\text { and heel }\end{array}$ & $\begin{array}{l}\text { Osgood } \\
\text { Schlatter, } \\
\text { calcaneal }\end{array}$ \\
\hline $\begin{array}{l}\text { Zariczn } \\
\text { yj et al. } \\
1980\end{array}$ & $\mathrm{P}$ & $\begin{array}{l}\text { USA, } \\
\text { region, } \\
\text { events } \\
\text { na }\end{array}$ & 289 & $5-17$ & 1 year & $\begin{array}{l}\text { Incidence } \\
5.7 / 1000 \mathrm{~h} \\
\text { participation }\end{array}$ & na & $\begin{array}{l}\text { Knee, } \\
\text { ankle }\end{array}$ & na \\
\hline $\begin{array}{l}\text { Coloun } \\
\text { et al. } \\
2001\end{array}$ & $\mathrm{R}$ & $\begin{array}{l}\text { Australi } \\
\text { a, } \\
\text { region, } \\
\text { clubs; } \\
\text { events } \\
\text { na }\end{array}$ & $\begin{array}{l}388 \\
211 / 177\end{array}$ & $7-15$ & 1 year & Prevalence $22 \%$ & na & $\begin{array}{l}\text { Knee, } \\
\text { ankle }\end{array}$ & na \\
\hline $\begin{array}{l}\text { Huxley } \\
\text { et al. } \\
2014\end{array}$ & $\mathrm{R}$ & $\begin{array}{l}\text { Australi } \\
\text { a, } \\
\text { region; } \\
\text { all } \\
\text { subgrou } \\
\text { ps of } \\
\text { events }\end{array}$ & $\begin{array}{l}103 \\
37 / 66\end{array}$ & $\begin{array}{l}13- \\
17\end{array}$ & 1 year & Prevalence $79 \%$ & $\begin{array}{l}\text { Overu } \\
\text { se } 76 \\
\%\end{array}$ & $\begin{array}{l}\text { Ankle or } \\
\text { foot, } \\
\text { lower leg }\end{array}$ & $\begin{array}{l}\text { Sprains, } \\
\text { bone } \\
\text { stress }\end{array}$ \\
\hline \multicolumn{10}{|c|}{ School setting } \\
\hline $\begin{array}{l}\text { Watson } \\
\text { and } \\
\text { DiMarti } \\
\text { no, } \\
1987\end{array}$ & $\mathrm{P}$ & $\begin{array}{l}\text { USA, } \\
\text { high } \\
\text { school; } \\
\text { all } \\
\text { events } \\
\text { except } \\
\text { throws, } \\
\text { long } \\
\text { jump }\end{array}$ & $\begin{array}{l}234 \\
156 / 78\end{array}$ & $\begin{array}{l}14- \\
18\end{array}$ & $\begin{array}{l}77 \\
\text { days }\end{array}$ & $\begin{array}{l}\text { Incidence } 7.5 / 100 \\
\text { athletes }\end{array}$ & $\begin{array}{l}\text { Acute } \\
\text { non- } \\
\text { contac } \\
\text { t or } \\
\text { overu } \\
\text { se } \\
83 \%\end{array}$ & $\begin{array}{l}\text { Lower } \\
\text { leg, } \\
\text { ankle }\end{array}$ & $\begin{array}{l}\text { Post } \\
\text { tibialis } \\
\text { syndrom } \\
\text { e, } \\
\text { sprained } \\
\text { ankle }\end{array}$ \\
\hline $\begin{array}{l}\text { Pierpoi } \\
\text { nt et al. } \\
2016\end{array}$ & $\mathrm{P}$ & $\begin{array}{l}\text { USA, } \\
\text { high } \\
\text { school; } \\
\text { all } \\
\text { events }\end{array}$ & na & $\begin{array}{l}14- \\
17\end{array}$ & $\begin{array}{l}5 \\
\text { years }\end{array}$ & $\begin{array}{l}\text { Incidence } \\
0.84 / 1000 \text { athlete } \\
\text { exposures }\end{array}$ & $\begin{array}{l}\text { Acute } \\
\text { non- } \\
\text { contac } \\
\text { t or } \\
\text { overu } \\
\text { se } \\
75 \%\end{array}$ & $\begin{array}{l}\text { Thigh/up } \\
\text { per leg, } \\
\text { lower leg }\end{array}$ & $\begin{array}{l}\text { Strains, } \\
\text { sprains }\end{array}$ \\
\hline
\end{tabular}




\begin{tabular}{|c|c|c|c|c|c|c|c|c|c|}
\hline $\begin{array}{l}\text { Rebella } \\
\text { et al. } \\
2008\end{array}$ & $P$ & $\begin{array}{l}\text { USA, } \\
\text { high } \\
\text { school, } \\
\text { pole } \\
\text { vault }\end{array}$ & $\begin{array}{l}140 \\
76 / 64\end{array}$ & $\begin{array}{l}15- \\
17\end{array}$ & $\begin{array}{l}\text { Two } \\
\text { seaso } \\
\text { ns }\end{array}$ & $\begin{array}{l}\text { Incidence } \\
7.1 / 1000 \text { athlete } \\
\text { exposures }\end{array}$ & $\begin{array}{l}\text { Overu } \\
\text { se } \\
73 \%\end{array}$ & $\begin{array}{l}\text { Low } \\
\text { back, } \\
\text { posterior } \\
\text { thigh }\end{array}$ & $\begin{array}{l}\text { Strains, } \\
\text { sprains }\end{array}$ \\
\hline
\end{tabular}

$\mathrm{P}$, prospective; $\mathrm{R}$, retrospective; na, not available.

${ }^{*}$ Reported in the paper, not the sum of the athletes because some competed in more than one discipline.

${ }^{* *}$ As reported in the original paper, comparative value varies.

***Two most commonly reported.

Table 2. Results from the cross-sectional survey reference group of coaches and parents $(n=20)$ (all did not provide an answer to every question)

\begin{tabular}{|c|c|c|}
\hline Theme & Category & $\begin{array}{l}\text { Example of quotes from coaches } \\
\text { and parents }\end{array}$ \\
\hline \multirow[t]{2}{*}{ Injury complaints } & Pain & $\begin{array}{l}\text { Child athletes in general often } \\
\text { experience pain in the knees and } \\
\text { feet. Among throwers, however, } \\
\text { shoulder pain is the major } \\
\text { complaint }\end{array}$ \\
\hline & $\begin{array}{l}\text { Growth-related swelling and } \\
\text { soreness }\end{array}$ & $\begin{array}{l}\text { Typical health complaints include } \\
\text { sore heels, sore Achilles tendons, } \\
\text { and sore knees. Knee soreness is } \\
\text { usually located beneath the knee } \\
\text { caps, i.e. Mb. Schlatter }\end{array}$ \\
\hline \multirow[t]{3}{*}{ IIIness complaints } & Infections & $\begin{array}{l}\text { In middle adolescence (14-15 } \\
\text { years), colds and other infectious } \\
\text { diseases are a recurring problem }\end{array}$ \\
\hline & Allergy & $\begin{array}{l}\text { Allergies are a recurring problem. } \\
\text { Among girls, they can progress to } \\
\text { reactive or cold air asthma }\end{array}$ \\
\hline & Insomnia & $\begin{array}{l}\text { The young athletes cannot fall } \\
\text { asleep after lying in bed playing } \\
\text { with their cell phones or tablets }\end{array}$ \\
\hline Causal mechanisms & Insufficient recovery & $\begin{array}{l}\text { It is hard to know what training load } \\
\text { is appropriate for children and } \\
\text { teens (considering pain and } \\
\text { growth-related problems), but it is } \\
\text { even more difficult to get a } \\
\text { teenager to accept that the body } \\
\text { needs recovery }\end{array}$ \\
\hline
\end{tabular}



while being constantly connected to the Internet and forcing oneself to be available at all times. The consequence is insufficient sleep when you have to have the last word in every social media conversation choose to eat for breakfast and on the competition day. Toast and some cornflakes ...

Table 3. Areas covered on the website www.friskfriidrott.se (Healthy Athletics): summary of information, recommendations and hands-on tools provided

\begin{tabular}{|c|c|c|}
\hline Heading & Subheading & $\begin{array}{l}\text { Information covered and hands-on } \\
\text { advice/tools }\end{array}$ \\
\hline \multirow[t]{4}{*}{$\begin{array}{l}\text { Athletics for a young athlete's } \\
\text { wellbeing }\end{array}$} & $\begin{array}{l}\text { Athletics for a young athlete's } \\
\text { wellbeing }\end{array}$ & $\begin{array}{l}\text { General information on participation } \\
\text { in sports; sport should be pursued } \\
\text { from the perspective of child rights }\end{array}$ \\
\hline & & $\begin{array}{l}\text { PDF file on "Convention on the } \\
\text { Rights of the Child" provided by the } \\
\text { Swedish National Sports Federation } \\
\text { (RF) }\end{array}$ \\
\hline & & $\begin{array}{l}\text { Links to the RF website providing } \\
\text { additional material on "training the } \\
\text { child athlete" }\end{array}$ \\
\hline & & $\begin{array}{l}\text { References to scientific literature } \\
\text { and books for further reading }\end{array}$ \\
\hline \multirow[t]{4}{*}{ Planning for training } & $\begin{array}{l}\text { Long-term perspective of planning } \\
\text { for training }\end{array}$ & $\begin{array}{l}\text { The basic principles for long-term } \\
\text { youth development and on what } \\
\text { happens in the body when you train }\end{array}$ \\
\hline & Training load & $\begin{array}{l}\text { The overall principles of training and } \\
\text { the process of biological adaptation }\end{array}$ \\
\hline & Training puzzle & $\begin{array}{l}\text { PDF file with tools describing how a } \\
\text { training session could be planned (in } \\
\text { the format of a puzzle) }\end{array}$ \\
\hline & & $\begin{array}{l}\text { References to scientific literature } \\
\text { and books for further reading. } \\
\text { References to Swedish Athletics } \\
\text { educational material for coaches }\end{array}$ \\
\hline \multirow[t]{2}{*}{ Puberty and training } & Growth spurt & $\begin{array}{l}\text { Information regarding the growing } \\
\text { child }\end{array}$ \\
\hline & & $\begin{array}{l}\text { Illustrations displaying growth zones; } \\
\text { information regarding susceptible } \\
\text { body locations in youths }\end{array}$ \\
\hline
\end{tabular}


Training the growing athlete

Training the female athlete

Recovery

Avoiding injuries and ill-health

About injuries

The most common injuries in Athletics

Recovery

Diet

Sleep

Sustainable athletics

Causes of injuries in youth sport

Injury prevention
Screening athletes; possible benefits and limitations

About pain

What happens in the body during an injury?

The most common injuries in Athletics

Information of what and how to train during a growth spurt as well during growth

How to train during the different phases of the menstrual cycle

References to scientific literature and books for further reading. References to Swedish Athletics educational material for coaches

General information regarding recovery. Focus on diet and sleep. Why you need to eat, why you need to sleep

PDF files with meal planning and suggestions on snacks

Information regarding specific recommendations for the growing child athlete

References to scientific literature and books for further reading

General background information how to systematically work with injury prevention, what might cause injuries in sport

Information regarding the current scientific base of knowledge on injuries in youth athletics

Link to the FIFA 11+ injury prevention programme

General information about physical health evaluation of the child athlete

References to scientific literature and books for further reading

Information describing different kinds of pain conditions, e.g. pain due to muscle soreness, overload of growth/training, etc. and recommendations on how these various conditions should be managed at the early stage

Information describing the three phases of the healing process. Information regarding pain inhibition

Recommendation on early secondary prevention strategies for the most common injuries related to overuse reported in the sport; e.g. management of shin splints, pain problems related to growth in Sever's- and Osgood Schlatter 
Illnesses

Rehabilitation

Mental illness

Management of acute traumatic injuries
Illnesses

Rehabilitation of injuries and return to sports (RTS)

Mental illness

Actions in case of acute (sudden) injuries and other conditions disease. All traumatic injuries referred to examination by a medical professional

Illustrations of the most common injuries in youth athletics

Video with taping instructions for knees and heels (Schlatter and Sever's disease)

Recommendations on early management of the most common illnesses in child (e.g. colds, asthma, eating disorders). For more specific questions, recommendations to contact their general practitioner

Contact information on where to turn for an eating disorder. Links to websites and telephone number provided

References to scientific literature and books for further reading

Information describing the general principles of rehabilitation.

Recommendations that this process should be managed by a certified sports physical therapist

Information regarding the recommended principals of RTS

Information about mental health and ill health

Contact information on where to turn if yourself, a peer or a relative is not feeling well. Links to websites and telephone numbers provided. In case of emergency,

recommendations to call 112

Information regarding the two most common injuries in athletics for acute care: ankle sprain and hamstring strain. The actions at PRICE and POLICE described

Video describing the PRICE procedure for acute ankle sprains and hamstring strains

In case of suspected concussion, recommendations to contact emergency care

In case of emergency, recommendations to call 112

Information on Swedish Sport's guidelines, which clearly state: sports for children and young people 


\section{Bullying and violations}

Sexual assault

\#metoo Swedish Athletics

Anti-doping
Anti-doping should be pursued from the perspective of a child rights and comply with the United Nations Convention on the Rights of the Child. "Children and young people should be able to participate in sport without risk of being violated in any way." RF

Information on bullying and violation and preventive work

Information about sexual harassment and preventive work

Information about the work performed in Swedish Athletics as a follow-up on \#metoo

Contact information on where to turn if yourself or you suspect that your child/a peer might be exposed to some form of harassment or the like. Links to websites and telephone number provided. In case of emergency, recommendations to call 112

Links to the RF and Swedish Athletics website providing further information and additional material such as guidelines and policies. Educational material

Information on the rules that apply to athletes under the age of 16 years. Information about medication and the risks with consuming dietary supplements

Links to the RF and Swedish Athletics website providing antidoping material

RF, Riksidrottsförbundet (the Swedish National Sports Federation); PRICE, Protect, Rest, Ice, Compression,

Elevation; POLICE, Protect, Optimal, Loading, Ice, Compression, Elevation. 